\title{
Association of HOMER1 rs2290639 with suicide attempts in Hong Kong Chinese and the potentially functional role of this polymorphism
}

\author{
Shitao Rao ${ }^{1}$, Marco H. B. Lam², Venus S. Y. Yeung ${ }^{1}$, Yun Kwok Wing ${ }^{2}$ and Mary Miu Yee Waye ${ }^{\text {* }}$
}

\begin{abstract}
Objective: Animal evidence and genetic studies suggest that HOMER1 (homer homolog 1) is involved in the etiology of suicidal behavior and major depression disorder (MDD). However, most of genetic studies were performed in Caucasians and the potentially functional role of associated polymorphisms in HOMER1 was seldom reported. The purpose of this study was to investigate the association of a HOMER1 polymorphism rs2290639 with suicide attempts (SA) and MDD in Hong Kong Chinese, and then briefly elucidate the potentially functional role of the associated polymorphism.
\end{abstract}

Methods: NEO personality inventory, impulsiveness and depression rating scales were completed by the subjects. The association studies of HOMER1 rs2290639 with SA or MDD were performed by case-control association studies. The bioinformatics analyses were adapted to predict potential transcription factors binding sites for the associated polymorphism.

Results: The association studies and meta-analysis suggested that the HOMER1 rs2290639 was significantly associated with susceptibility to SA but seemed not to be associated with MDD in Hong Kong Chinese. This polymorphism might affect the transcription of the HOMER1 gene through interacting with a reliable transcription factor as found by three of four bioinformatics tools. In addition, close correlations between impulsiveness and NEO personality five factors were found in SA and MDD patients, which provide a possible way to assess the impulsiveness of patients through subjects' personality profiles for Hong Kong Chinese.

Conclusions: The HOMER1 rs2290639 polymorphism was significantly associated with susceptibility to SA in Hong Kong Chinese affected by psychiatric disorders, which might be explained by the potentially functional role of this polymorphism.

Keywords: Suicidal attempts, Major depression disorder, HOMER1 rs2290639, Meta-analysis, Functional role, Psychometric properties

\section{Background}

Approximately 1 million people worldwide die by suicide each year, accounting for $1.5 \%$ of death by all causes

\footnotetext{
*Correspondence: mary-waye@cuhk.edu.hk

${ }^{1}$ Croucher Laboratory for Human Genomics, Rm324A, Lo Kwee-Seong Integrated Biomedical Sciences Building, School of Biomedical Sciences, Area 39; The Nethersole School of Nursing, The Chinese University of Hong Kong, Shatin, N.T., Hong Kong

Full list of author information is available at the end of the article
}

(Mann 2003). Completed suicide is the 10th leading cause of death worldwide and suicide attempts (i.e. nonfatal suicidal behavior) is up to 20 times more frequent than completed suicide (Hawton and van Heeringen 2009; Varnik 2012), which confirms that suicidal behavior means a heavy burden on the health-care system and alerts the severity of its corrosive social impact (Miller et al. 2012b). 
Suicidal behavior is generally regarded as a complex health and social issue that is believed to manifest as a combination of many factors, including environmental and genetic factors (Sher 2011). Genetic studies, such as family, twin and adoption studies, have consistently demonstrated that genetic factors appear to be involved in suicidal behavior (Wender et al. 1986; Roy et al. 1997; Li et al. 2010). These studies also illustrate that the predisposition to suicidal behavior is partly dependent on the presence of psychiatric disorders, such as bipolar disorder, schizophrenia, alcoholism and major depression disorder (MDD). Among these diseases, MDD is the most important predicting factor of suicidal behavior and eventually about $10 \%$ of MDD patients may end up taking their lives by committing suicide (Winokur and Tsuang 1975). In addition, a large body of evidence indicates that various neural abnormalities, such as the dysfunction of glutamate receptor signaling and the reduced number and abnormal morphology of dendritic spines, are involved in the pathogenesis of many different brain diseases and suicidal behavior (Giuffrida et al. 2005; Govek et al. 2004; Szumlinksi et al. 2005).

Homer homolog 1 gene (HOMER1) is expressed pronouncedly in nervous system (Su et al. 2004). Previous studies reported that the encoded HOMER1 protein was involved in glutamatergic synapses and spine morphogenesis (Naisbitt et al. 1999; Tu et al. 1998; Hayashi et al. 2009; Govek et al. 2004), which suggested that the HOMER1 gene may be an important candidate gene in the etiology of MDD and suicidal behavior. HOMER1a is a short isoform of HOMER1 and has a low expression level under normal conditions, but its expression level increases significantly after receiving neuronal activation (Brakeman et al. 1997). HOMER1b and 1c, the long isoforms of HOMER1, are constitutively expressed in vivo and in vitro without any activation (Kato et al. 1998). Both of the short and long isoforms share a conserved amino-terminal Enabled/vasodilator-stimulated phosphoprotein homolog 1 (EVH1) domain. This domain has a strong binding affinity to a proline-rich sequence, which can be found in Group 1 metabotropic glutamate receptors, NMDA glutamate receptor and scaffolding protein SHANK (Tu et al. 1998; Naisbitt et al. 1999; Hayashi et al. 2009). Moreover, Hayashi et al. demonstrated that HOMER1 and SHANK together formed a mesh-like matrix structure, which could serve as an assembly platform for other postsynaptic density (PSD) protein, such as mGluR1 $\alpha / 5$, NMDA receptor and IP3 receptor (Hayashi et al. 2009; Shiraishi-Yamaguchi and Furuichi 2007). In addition, both long and short isoforms of HOMER1 protein could regulate cell-surface targeting and clustering of mGluR $1 \alpha / 5$ (Roche et al. 1999; Ango et al. 2002; Serge et al. 2002). SHANK protein is an adaptor for the NMDA receptor/PSD-95 complex (Shiraishi-Yamaguchi and Furuichi 2007). Thus, we believe that HOMER1 protein has the ability to interact directly with $m G l u R 1 \alpha / 5$ and indirectly with NMDA receptors at glutamatergic synapses. Moreover, the HOMER1 variants are involved in regulating spine morphogenesis, which is closely correlated with learning and memory performance (Govek et al. 2004). In addition, chronic stress could down-regulate the expression of HOMER1 in the prefrontal cortex of rat, and the effect could be reversed with antidepressant administration (Orsetti et al. 2008, 2009). Moreover, HOMER1 knockout mice showed some changes that were similar to those observed in animal stress paradigms (Szumlinksi et al. 2005; Schmidt and Duman 2007), and these symptomatic phenotypes could be extinguished by overexpression of HOMER1 protein (Lominac et al. 2005).

Although there are several lines of evidence supporting the association of HOMER1 polymorphisms with psychiatric disorders or suicidal behavior in Caucasians, the results may be significantly different in other ethnic populations due to the widely reported genetic heterogeneity (Wang et al. 2014; Yin et al. 2015; Thean et al. 2012). In humans, HOMER1 is localized to chromosome 5q14.2, and several linkage studies demonstrated that susceptibility loci on this chromosome were significantly associated with schizoaffective disorder (Levinson et al. 2000; Gurling and Brynjolfsson 2001). Furthermore, Rietschel et al. found that two polymorphisms were nominally significantly associated with MDD by a genome-wide association study (Rietschel et al. 2010). One of the two polymorphisms is located in a putative regulatory region of HOMER1 and had significant association with prefrontal activity during executive cognition. Additionally, HOMER1 rs2290639 has been found to be associated with baseline psychopathology and antipsychotic treatment response in schizophrenic patients (Spellmann et al. 2011). Moreover, Strauss et al. performed a casecontrol association study in northern America and obtained a significant genotypic association between the rs2290639 and suicide attempts (Strauss et al. 2012).

In addition, broader personality profiles, impulsiveness and depression had long been linked with suicidal behavior and MDD (Duberstein 1995; Roy 2001; Corruble et al. 1999; Goldney et al. 2002; Horesh et al. 1997). The broader personality profiles include five-factor models: openness to experience $(\mathrm{O})$, conscientiousness $(\mathrm{C})$, extraversion $(\mathrm{E})$, agreeableness $(\mathrm{A})$, and neuroticism $(\mathrm{N})$. Previous studies found that all the five factors were linked with suicidal behavior (Duberstein 1995; Roy 2001). Besides, it was believed that impulsive or depressed subjects had a higher chance of suicide attempts (Corruble et al. 1999; Horesh et al. 1997). 
In this study, we aimed to investigate whether the HOMER1 rs2290639 was associated with SA in Hong Kong Chinese since the previous association studies of the rs2290639 with SA were performed in Caucasians and the genetic heterogeneity exists between Caucasians and Chinese. The dbSNP database (release 142) shows that the allele frequencies of rs2290639 in Chinese Han Beijing (CHB) are 0.427 for A allele and 0.573 for T allele, but in Utah residents with Northern and Western European ancestry (CEU), they are 0.596 for A allele and 0.404 for $\mathrm{T}$ allele. Moreover, we also explored if the polymorphism was associated with MDD in Hong Kong Chinese. Besides, the potentially functional role of rs2290639 was briefly elucidated in this study. Another aim of this study was to find out whether there was any significant difference in psychometric properties among different groups of SA, non-SA, MDD and HC subjects.

\section{Methods}

\section{Participants}

Subjects who had their visit to either in-patient psychiatric unit of Shatin Hospital (Shatin, New Territories, Hong Kong) or out-patient psychiatric clinic of Prince of Wales Hospital (New Territories, Hong Kong) were recruited into this study. An interview was conducted for the subjects by experienced clinical psychiatrists, who acquired the subjects' demographics, including sex, age, whether they had full-time job or study and a history of suicide attempts (SA). Besides, The Chinese-Bilingual Structured Clinical Interview for the Diagnostic and Statistical Manual of Mental Disorders, 4th Edition (Axis I, Patient version) (CB-SCID-I/P) was also carried out for the subjects to ascertain their depression status as it has a high prevalence in SA patients (Segal et al. 1994). Those subjects who suffered from mental retardation or dementia were excluded from this study. Finally, 117 SA patients (34 men and 83 women) and 167 MDD patients (44 men and 123 women) were included into this study. The mean age of SA patients was $38.5 \pm 11.8$ and that of MDD patients was $41.3 \pm 11.9$. Besides, those subjects suffering from any kind of psychiatric disorder but not having a history of SA would be considered as non-suicide attempters (non-SA), and those not suffering from any kind of psychiatric disorder and also not having a history of SA would be grouped into healthy controls (HC). 198 nonSA subjects [ 87 men and 111 women, mean age $=39.6$ $( \pm 11.9)$ years] and 84 healthy controls [42 men and 42 women, mean age $=39.3( \pm 12.2)$ years $]$ were recruited into this study. Moreover, the detailed information of those subjects was reported in Table 1.

As shown in Table 1, there were 72 patients that suffered from a comorbid history of MDD and SA. In addition, there were 45 non-MDD SA patients, most of whom
Table 1 Information of SA, non-SA, MDD and non-MDD

\begin{tabular}{lccc}
\hline $\begin{array}{l}\text { Phenotypes/No. of } \\
\text { subjects }\end{array}$ & MDD & Non-MDD & Sub-total \\
\hline SA & 72 & 45 & 117 \\
Non-SA & 95 & 103 & 198 \\
Sub-total & 167 & 148 & 315 \\
\hline
\end{tabular}

$S A$ suicide attempts, non-SA non-suicide attempts, MDD major depression disorder, non-MDD subjects without major depression disorder

had other mental disorders, such as bipolar disorder, schizophrenia and other mental disorders. However, 8 of them did not suffer from any mental disorders. Furthermore, all the 103 non-SA and non-MDD subjects had other mental disorders. Given the number of subjects with either bipolar disorder or schizophrenia was very small $(<82)$, we did not perform association studies of rs2290639 with the two disorders. But the two disorders were considered as covariates when comparing SA group with non-SA group in rs2290639.

All the participants are Han Chinese in origin. Written informed consents were obtained from all the subjects. This study was reviewed and approved by the Joint Chinese University of Hong Kong-New Territories East Cluster Clinical Research Ethics Committee (CRE Reference No. 2006.393).

\section{Psychometric properties of subjects}

All patients completed three clinical scales including NEO Personality Five-factor Inventory, Barratt Impulsiveness Scale (BIS) and Hospital Anxiety and Depression Scale (HADS). The NEO Personality Five-factor Inventory is a simplified version of NEO Personality Inventory Revised (NEO PI-R). It scores individuals on five personality dimensions: openness to experience $(\mathrm{O})$, conscientiousness $(\mathrm{C})$, extroversion $(\mathrm{E})$, agreeableness (A) and neuroticism (N). A Chinese translated version of the inventory has been validated and it was supported by spouse rating of one's personality. The test-retest reliability was found to be high (Yang et al. 1999). Moreover, the inventory was found to have high internal consistency in assessing personality traits (Eggert et al. 2007). BIS is a self-report measurement of impulsiveness. Translation (translated from English to Chinese) and back translation (back translated into English) has been performed in a study to assess the accuracy of translation (Yao et al. 2007; Patton et al. 1995). HADS is a selfrated scale which consisted of anxiety and depression subscales. The Chinese version has been translated and demonstrated good agreement with the English version (Leung et al. 1993, 1999). It is found to be reliable in measuring the severity of emotional disorder, especially for MDD (Bjelland et al. 2002). 


\section{SNPs genotyping}

Genomic DNA was extracted from two milliliters of saliva reagent using the Oragene ${ }^{\mathrm{TM}}$ DNA self-collection kit according to the manufacturer's instruction (DNA Genotek, Inc., Ottawa, Canada). After DNA extraction, the concentration of genomic DNA was determined by Nanodrop 2000c spectrophotometer (Thermo Fisher Scientific Inc., MA, US). For PCR reactions, a $10 \mu \mathrm{l}$ volume of PCR mixture containing 100 ng of genomic DNA was used for standard ABI TaqMan ${ }^{\circledR}$ SNP Genotyping assays. The mixture was firstly treated by activation of the uracil$\mathrm{N}$-glycosylase for $2 \mathrm{~min}$ at $50{ }^{\circ} \mathrm{C}$, followed by denaturation for $10 \mathrm{~min}$ at $95^{\circ} \mathrm{C}$ and amplification over 45 cycles of $15 \mathrm{~s}$ at $95^{\circ} \mathrm{C}$ and $1 \mathrm{~min}$ at $60{ }^{\circ} \mathrm{C}$ using 'Genotyping' option with three steps (pre-read, amplification and postread) in ABI ViiA 7 Real-Time PCR system (Applied Biosystems, Foster City, California, USA).

\section{Bioinformatics prediction of transcription factors binding sites for HOMER 1 rs2290639}

To investigate the possible molecular mechanism of the rs2290639, we performed the prediction of transcription factors binding sites for this polymorphism using four bioinformatics tools: P-Match v1.0 (TRANSFAC v6.0, Group of Matrices: vertebrates, Profiles: nerve-systemspecific), PROMO v3.0.2 (TRANSFAC v8.3), JASPAR (JASPAR CORE Vertebrata) and AliBaba 2.1 (TRANSFAC v4.0) (Messeguer et al. 2002; Mathelier et al. 2014; Cartharius et al. 2005). The transcription factor found by more than one tool was considered as a potentially reliable binding factor.

\section{Statistical analyses}

Comparisons of continuous and categorical variables were accomplished by $\mathrm{t}$ test and Chi square test respectively using SPSS program (version 20.0). Fisher's exact test would be adopted when low cell counts or expected frequencies occurred in the analyses. Comparisons of more than two groups with continuous data would be performed by one-way ANOVA followed by Post Hoc Multiple Comparisons (Bonferroni). Comparisons of more than two groups with categorical data would be carried out by Chi square test followed by Mann-Whitney test. The correlations between impulsiveness and NEO personality five factors in SA and MDD patients were performed using bivariate correlation analysis. Hardy-Weinberg equilibrium (HWE) tests were used to examine the fit of the genotypic distributions of rs2290639 to equilibrium in each sample. The genotype and allele frequencies were compared by Chi square test or Fisher's exact test. The odds ratio (OR) values and $95 \%$ confidence intervals
(CI) were determined by logistic regression analysis after adjustment of confounding factors. The different models' power were calculated separately in Power and Sample Size Program (Dupont and Plummer 1990). Meta-analysis was conducted in StateSE (version 12.0, StataCorp LP, Texas, USA) (Boston and Sumner 2003). $\mathrm{I}^{2}$ statistics were adopted for the assessment of heterogeneity between different studies (Higgins and Thompson 2004; Trikalinos et al. 2008). Based on $I^{2}$ values, different effect models, fixed effect model or random effect model, were adopted to meta-analysis. $P$ values ( 2 -tailed) of $<0.05$ were considered statistically significant.

\section{Results}

Demographics and psychometric properties of SA, non-SA, MDD and $\mathrm{HC}$

As shown in Fig. 1 and Additional file 1: Table S1, the percentage of female in SA and MDD patients was significantly higher than that in $\mathrm{HC}$ ( $\mathrm{P}$ value $=0.003$ and $<0.001$ respectively). Besides, there was also a significant difference between SA and non-SA patients ( $P$ value $=0.009$ ). For the status of employment, SA patients had a significantly lower percentage of employment than the other three groups ( $\mathrm{P}$ value $=0.002,0.031$ and $<0.001$ for non-SA, MDD and $\mathrm{HC}$ respectively). Furthermore, $\mathrm{HC}$ had a significantly higher percentage of employment than non-SA and MDD patients ( $\mathrm{P}$ value $<0.001$ and $<0.001$ respectively). However, there was no significant difference of age in the four groups (P value $>0.299$ ).

For the psychometric properties of subjects, MDD patients scored significantly higher in HADS score compared to non-SA patients and HC ( $P$ value $=0.001$ and $<0.001$, respectively, Fig. 2 and Additional file 1: Table S1). Besides, the relationships between impulsiveness and NEO personality five factors in SA and MDD patients were to be investigated. In suicide attempters, impulsiveness was inversely correlated with NEO-conscientiousness $(\mathrm{r}=-0.55, \mathrm{P}<0.001)$, NEO-extroversion $(\mathrm{r}=-0.38, \mathrm{P}<0.001)$, NEO-agreeableness $(\mathrm{r}=-0.46$, $\mathrm{P}<0.001$ ), but positively correlated with NEO-neuroticism $(r=0.41, P<0.001)$. In MDD patients, impulsiveness had significantly inverse correlations with NEO-openness to experience $(\mathrm{r}=-0.31, \mathrm{P}<0.001)$, NEO-conscientiousness $(\mathrm{r}=-0.55, \mathrm{P}<0.001)$, NEOextroversion $(\mathrm{r}=-0.28, \mathrm{P}=0.001)$ and NEO-agreeableness $(\mathrm{r}=-0.37, \mathrm{P}<0.001)$, but had positive correlation with NEO-neuroticism $(\mathrm{r}=0.40, \mathrm{P}<0.001)$. However, we did not find that there was any significant difference for BIS score and NEO personality five factors in the four groups (Fig. 2 and Additional file 1: Table S1, data not shown for NEO personality five factors). 

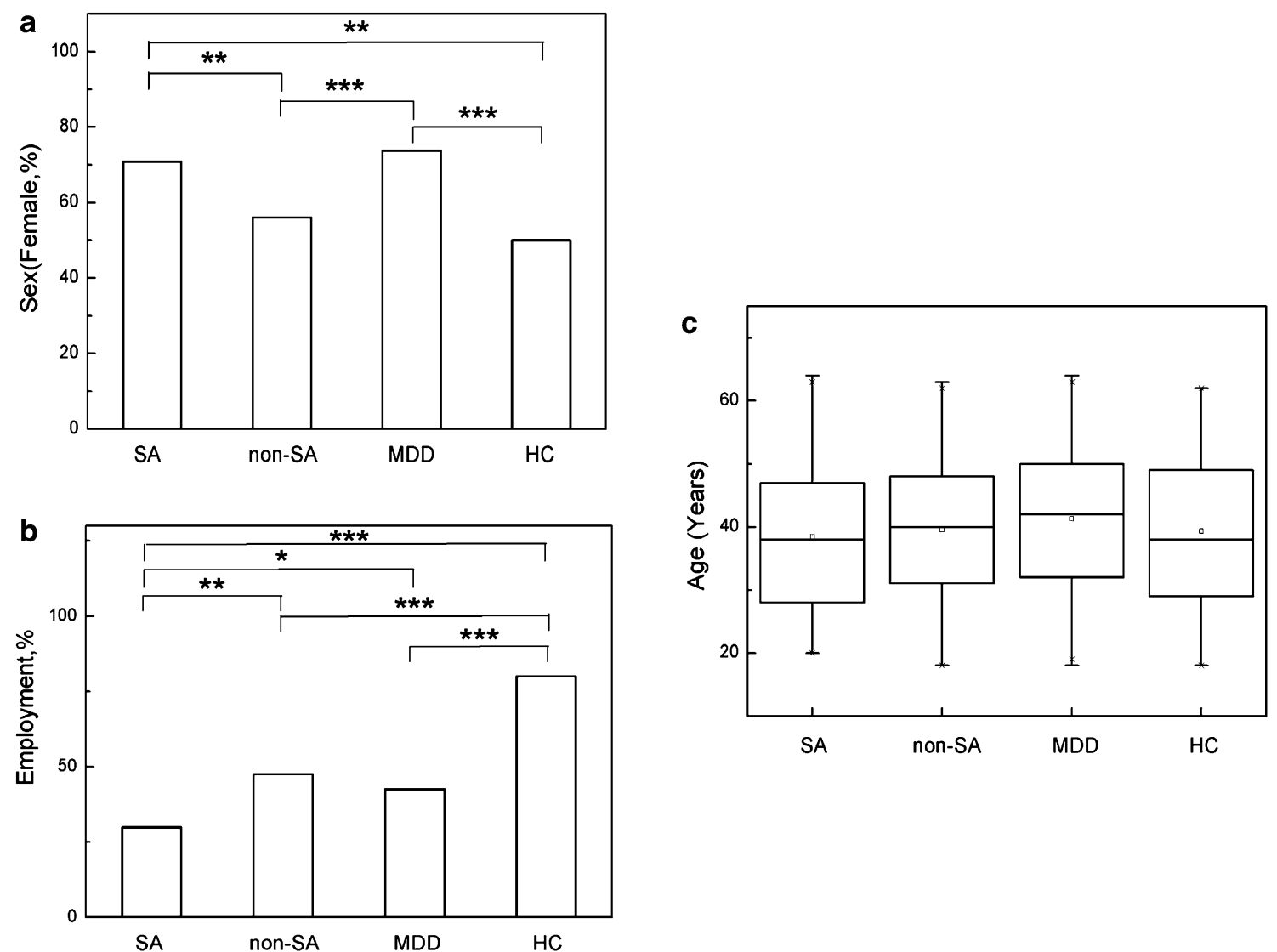

Fig. 1 Demographics of SA, non-SA, MDD and HC (a sex, b employment, $\mathbf{c}$ age). SA suicide attempts patients, non-SA non-suicide attempts patients with psychiatric disorders, MDD major depressive disorder patients, HC healthy controls; data are presented in Median (Q1 and Q3) for age and in percentage for sex and employment

\section{Association study of HOMER1 rs2290639 with suicide attempts and major depression disorder}

The number of successfully genotyped DNA samples in SA, non-SA, MDD and HC were 111, 189, 160 and 84 respectively. The distribution of $\mathrm{rs} 2290639$ in $\mathrm{HC}$ was in accordance with the Hardy-Weinberg equilibrium (P value $=0.236$ ). For the association study, rs2290639 was found to be significantly associated with suicide attempts in homozygous model ( $\mathrm{P}$ value $=0.033$, Table 2 ), and it remained significant in logistic regression analysis after controlling for covariates and after 2000 permutation tests $(\mathrm{P}$ value $=0.032$ and 0.043 , respectively). Moreover, the results in genotypic model also implied that this polymorphism was significantly associated with suicide attempts (adjusted $\mathrm{P}$ value after permutation tests is equal to 0.008). In the recessive model, SA patients had a significantly higher frequency of AA homozygote than non-SA subjects (P value $=0.004$ ), and the difference was still significant in logistic regression analysis and after permutations tests $(\mathrm{P}$ value $=0.005$ and 0.005 , respectively. Table 2). The results of logistic regression analysis also indicated that the subjects with AA homozygote had 2.78-fold higher odds of SA than those with T-carrier genotypes (OR 2.78; 95 \% CI 1.35-5.71). Following this finding, we further investigated whether there was any difference of psychometric properties between SA patients with homozygote (AA) and those with T-carrier genotypes. However, we did not find any difference in BIS score, HADS score or NEO personality five factors (Additional file 1: Fig. S1). Regarding to the SA $(n=72)$ and non-SA $(\mathrm{n}=95)$ in subjects with MDD in this study (Table 1), the statistical analyses also demonstrated that there were significant associations of this polymorphism with SA ( $P$ value $=0.006$ in Chi square test and adjusted $P$ value $=0.007$ in logistic regression analysis). Besides, no significant difference was found in genotypic frequency of rs2290639 between SA and $\mathrm{HC}$ as well as between MDD and HC (Table 2).

In addition, a meta-analysis of this polymorphism with SA was performed including this study and a previous association study (Strauss et al. 2012). In total, 222 SA patients and 294 non-SA subjects were 

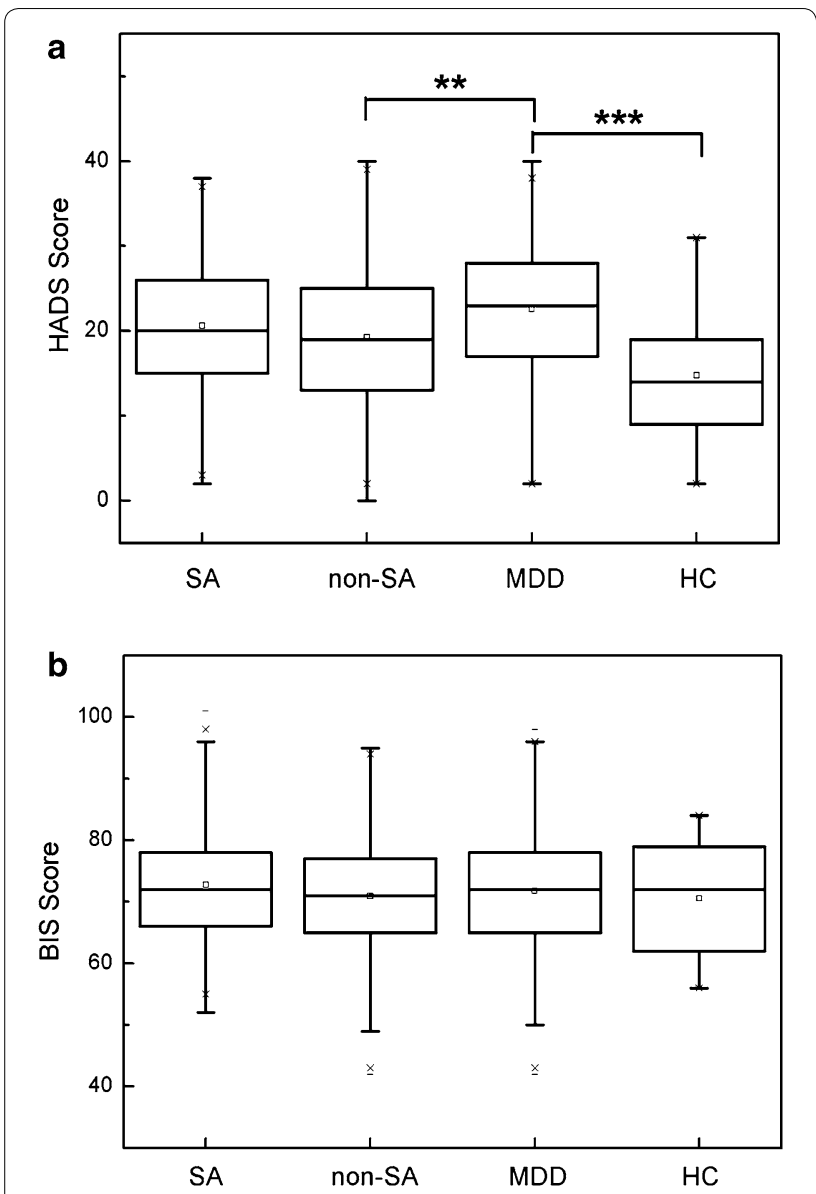

Fig. 2 Psychometric properties of SA, non-SA, MDD and HC (a HADS score, b BIS score). SA suicide attempt patients, non-SA non-suicide attempts subjects with psychiatric disorders, MDD major depressive disorder patients, $\mathrm{HC}$ healthy controls; data are presented in Median (Q1 and Q3)

included in this meta-analysis. Regarding to a moderate heterogeneity across the two studies, random effect model was adapted to the heterozygous and recessive meta-analyses as the model allows for heterogeneity across studies (Trikalinos et al. 2008). The allele-A with lower frequency in our sample was considered as the minor allele. In recessive analyses (AA vs. AT $+\mathrm{TT}$ ) of rs2290639, there was a significant difference between SA and non-SA groups in Hong Kong Chinese sample [OR (95\% CI) $2.78(1.35-5.71)]$ and in the overall test [OR (95 \% CI) $2.01(1.16-3.52)]$, but not in Strauss' sample [OR (95 \% CI) 1.57 (0.85-2.89)] (Table 3). Moreover, this polymorphism was also significantly associated with SA in homozygous model [OR (95\% CI) 1.86 (1.05-3.29)]. Although there was a significant association in Strauss' sample in heterozygous model [OR (95 \% CI) $0.31(0.15-0.67)]$, this polymorphism was not significantly associated with SA in Hong Kong Chinese sample [OR (95\% CI) $0.74(0.43-1.26)]$ and in over-all test [OR $(95 \% \mathrm{CI}) 0.50(0.21-1.16)]$.

\section{Potentially functional role of HOMER1 rs2290639}

After prediction of potential binding regulatory elements by four bioinformatics tools, a transcription factor called C/EBP alpha (CEBPA) was found to be bound on rs2290639 and nearby nucleotides in three of the four tools (P-Match, Alibaba and JASPAR) (Fig. 3). Although there is a slight difference of bound nucleotides in the three tools, rs2290639 was covered by CEBPA in all the three tools. Miller et al. reported that CEBPA protein is a kind of bZIP transcription factor which can bind as a homodimer to certain enhancers (Miller et al. 2003). Moreover, previous studies reported that regulatory modules can be found in the promoter or exon regions of a gene, and it may also be located in the intron or downstream regions (Dong et al. 2010; Rosenthal et al. 1990; Pinaud et al. 1997; Pennacchio et al. 2013). Besides, the results of expression quantitative traits locus (eQTLs) demonstrated that rs2290639 was significantly associated with the expression level of the HOMER1 protein in thyroid tissue [P value $=5 \times 10^{-9}$, the Genotype-Tissue Expression (GTEx) project, V6]. The results also showed that the subjects with AA homozygous genotype have a lower expression level of the HOMER1 protein compared with the subjects with T-carrier genotypes (effect size $=-0.26$ ). Thus, we propose that rs2290639 together with nearby nucleotides may act as a potentially regulatory module playing a functional role in the transcription of HOMER1 gene, although the polymorphism was located on the downstream side of the HOMER1 gene. In addition, we found that this polymorphism was located in the promoter region of an uncharacterized gene called LOC101929201 in NCBI dbSNP database, and the distance between this polymorphism and the transcription start site of the gene is $635 \mathrm{bps}$. Therefore, rs2290639 may exert an important functional role through influencing the transcription of the LOC101929201 gene.

\section{Discussion}

This study suggested that HOMER1 rs2290639 was significantly associated with SA in Hong Kong Chinese. Furthermore, the logistic regression analysis implied that rs2290639 AA homozygote was significantly associated with the susceptibility to SA in genotypic, homozygous and recessive models in Hong Kong Chinese sample (Table 2). And all the associations remained significant after 2000 permutation tests. Although Strauss et al. also found there was an association between the polymorphism and SA, the association was only found in heterozygous analysis according to the genotypic frequencies in Caucasians (Table 3). The different positively 
Table 2 Allele and genotype frequencies of HOMER1 rs2290639 in HC, SA, MDD and non-SA

\begin{tabular}{|c|c|c|c|c|c|c|c|c|c|c|c|}
\hline \multirow[t]{2}{*}{ Model } & \multirow{2}{*}{$\begin{array}{l}\mathrm{HC} \\
(n=84)\end{array}$} & \multirow{2}{*}{$\begin{array}{l}S A \\
(n=111)\end{array}$} & \multirow{2}{*}{$\begin{array}{l}\text { MDD } \\
(n=160)\end{array}$} & \multirow{2}{*}{$\begin{array}{l}\text { Non-SA } \\
(n=189)\end{array}$} & \multicolumn{2}{|c|}{ SA versus $H C$} & \multicolumn{3}{|c|}{ SA versus non-SA } & \multicolumn{2}{|c|}{ MDD versus $\mathrm{HC}$} \\
\hline & & & & & $\mathrm{P}\left(X^{2}\right)$ & P (logistic) & $\mathrm{P}\left(X^{2}\right)$ & P (logistic) & P (Perm) & $\mathrm{P}\left(X^{2}\right)$ & P (logistic) \\
\hline \multicolumn{12}{|l|}{ Allelic } \\
\hline A & $65(38.7)$ & $92(41.4)$ & $122(38.1)$ & $138(36.5)$ & 0.585 & 0.994 & 0.230 & 0.195 & - & 0.903 & 0.621 \\
\hline $\mathrm{T}$ & $103(61.3)$ & $130(58.6)$ & $198(61.9)$ & $240(63.5)$ & & & & & & & \\
\hline \multicolumn{12}{|c|}{ Genotypic } \\
\hline $\mathrm{AA}$ & $10(11.9)$ & $22(19.8)$ & $23(14.4)$ & $16(8.5)$ & 0.226 & 0.833 & 0.009 & 0.013 & 0.008 & 0.653 & 0.606 \\
\hline AT & 45 (53.6) & $48(43.3)$ & $76(47.5)$ & $106(56.1)$ & & & & & & & \\
\hline TT & $29(34.5)$ & $41(36.9)$ & $61(38.1)$ & $67(35.4)$ & & & & & & & \\
\hline \multicolumn{12}{|c|}{ Homozygous } \\
\hline $\mathrm{AA}$ & $10(11.9)$ & $22(19.8)$ & $23(14.4)$ & $16(8.5)$ & 0.326 & 0.844 & 0.033 & 0.032 & 0.043 & 0.839 & 0.823 \\
\hline $\mathrm{TT}$ & $29(34.5)$ & $41(36.9)$ & $61(38.1)$ & $67(35.4)$ & & & & & & & \\
\hline \multicolumn{12}{|c|}{ Heterozygous } \\
\hline AT & $45(53.6)$ & $48(43.3)$ & $76(47.5)$ & $106(56.1)$ & 0.377 & 0.308 & 0.253 & 0.262 & - & 0.455 & 0.388 \\
\hline TT & $29(34.5)$ & 41 (36.9) & $61(38.1)$ & $67(45.4)$ & & & & & & & \\
\hline \multicolumn{12}{|l|}{ Recessive } \\
\hline $\mathrm{AA}$ & $10(11.9)$ & $22(19.8)$ & $23(14.4)$ & $16(8.5)$ & 0.139 & 0.354 & 0.004 & 0.005 & 0.005 & 0.592 & 0.568 \\
\hline$A T+T T$ & 74 (88.1) & 89 (80.2) & $137(85.6)$ & $173(91.5)$ & & & & & & & \\
\hline
\end{tabular}

$H C$ healthy controls, SA suicide attempt patients, MDD major depressive disorder patients, non-SA non-suicide attempts subjects with psychiatric disorders, OR odds ratio, $\mathrm{Cl}$ confidence interval. Data is shown in number (\%); $\mathrm{P}\left(X^{2}\right)$ : $\mathrm{P}$ value were calculated by $C$ hi square test; $\mathrm{P}$ (logistic): $\mathrm{P}$ value calculated by logistic regression analysis after controlling by sex and age in SA versus HC and MDD versus HC; P value calculated by logistic regression analysis after controlling by sex, age, MDD, bipolar disorder and schizophrenia in SA versus non-SA; P (Perm): adjusted P value after 2000 permutations tests for the significant results in Chi square tests; $P$ values below 0.05 are in italics

Table 3 Meta-analysis of association study of HOMER1 rs2290639 and suicide attempts in three different models

\begin{tabular}{|c|c|c|c|c|}
\hline \multirow{2}{*}{$\begin{array}{l}\text { Models } \\
\text { (rs2290639) }\end{array}$} & \multirow{2}{*}{$\begin{array}{l}\text { Hong Kong Chinese } \\
\text { sample } \\
\text { OR }(95 \% \mathrm{Cl})\end{array}$} & \multirow{2}{*}{$\begin{array}{l}\text { Strauss' sample } \\
\text { OR }(95 \% \mathrm{Cl})\end{array}$} & \multicolumn{2}{|l|}{ Overall test } \\
\hline & & & $\mathrm{OR}^{\mathrm{b}} 95 \% \mathrm{Cl}$ & $I^{2}(P)^{a}$ \\
\hline \multicolumn{5}{|l|}{ Homozygous } \\
\hline AA versus TT* & $2.36(1.08-5.19)$ & $1.43(0.63-3.24)$ & $1.86(1.05-3.29)$ & $0 \%(0.39)$ \\
\hline \multicolumn{5}{|l|}{ Heterozygous } \\
\hline AT versus TT* & $0.74(0.43-1.26)$ & $0.31(0.15-0.67)$ & $0.50(0.21-1.16)$ & $70.8 \%(0.06)$ \\
\hline \multicolumn{5}{|l|}{ Recessive } \\
\hline$A A$ versus $A T+T T^{*}$ & $2.78(1.35-5.71)$ & $1.57(0.85-2.89)$ & $2.01(1.16-3.52)$ & $28.7 \%(0.24)$ \\
\hline
\end{tabular}

The $\mathrm{OR}$ and $95 \% \mathrm{Cl}$ in significant associations were in italics; the genotype with an asterisk acts as the reference

a $\mathrm{I}^{2}(\mathrm{P})$ : heterogeneity test for meta-analysis (P value)

b Fixed effect model was adapted to homozygous meta-analysis and random effect model was employed to heterozygous and recessive meta-analyses

and negatively associated models in HOMER1 rs2290639 observed in Chinese and Caucasians might be explained by the variations existing in human genetic structure, i.e. different ethnic populations show significant discrepancies in allelic or genotypic frequencies (Schork et al. 2001; Altshuler et al. 2005). Therefore, it was worthwhile to perform a meta-analysis including samples recruited in this study and Strauss' study. According to the results of the meta-analysis, rs2290639 was significantly associated with SA in homozygous and recessive models (Table 3). Taken together, it is reasonable to conclude that HOMER1 rs2290639 was significantly associated with susceptibility to SA in both Caucasians and Chinese affected by psychiatric disorders.

In addition, the potentially molecular mechanism behind the significant association was briefly elucidated in this study. In silico analysis in four tools for predicting transcription factors binding sites found that a reliable transcription factor called CEBPA binds on rs2290639 and nearby nucleotides in three of the four tools (Fig. 3). Moreover, the eQTLs results also implied that there was a strong association of this polymorphism and the 


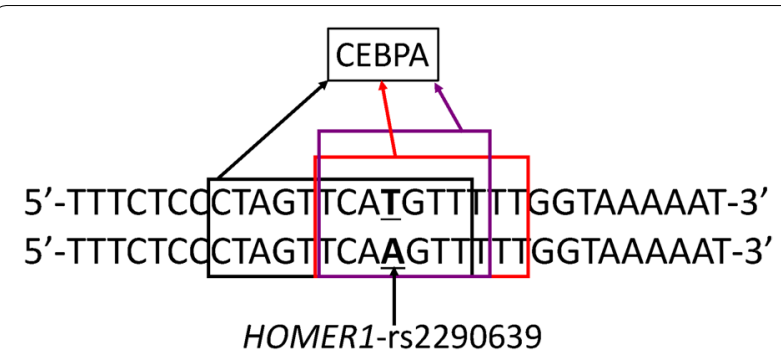

Fig. 3 Bioinformatics prediction of transcription factors binding sites for HOMER1 rs2290639. The predicted binding nucleotides by CEBPA in P-Match, Alibaba 2.1 and JASPAR are presented in black, red and purple boxes respectively

expression level of the HOMER1 protein. Although rs2290639 is located on the downstream region of the HOMER1 gene, this polymorphism together with nearby nucleotides may act as a regulatory module influencing the transcription of HOMER1 as the regulatory module could be located in the intron region or downstream region (Fiskerstrand et al. 1999; Lovejoy et al. 2003; Baum et al. 2008; Rosenthal et al. 1990). Previous studies reported that one repeat length polymorphism (STin2), albeit located in the second intron of SLC6A4 (serotonin transporter) gene, had functional role in the expression of SLC6A4 (Lovejoy et al. 2003; Fiskerstrand et al. 1999). Moreover, several polymorphisms or haplotypes in the first intron of $D G K H$ (diacylglycerol kinase eta) gene were reported to be associated with bipolar disorder in Caucasians and Chinese (Baum et al. 2008; Zeng et al. 2011). Our group found that a different polymorphism, also located in the first intron of $D G K H$ gene, was significantly associated with bipolar disorder in Hong Kong Chinese (Rao et al. 2015). Besides, Rosenthal et al. reported that an enhancer element was located downstream of the coding region in $M L C$ (myosin light chain) $1 / 3$ gene (Rosenthal et al. 1990). Thus, the regulatory function of rs2290639 and the interaction between rs2290639 and CEBPA are worthy to be investigated by further experimental approaches to determine how they influence the transcription of the HOMER1 gene.

Taken together, it is reasonable to propose that the significant association between rs2290639 and SA may be explained by the polymorphism's potentially functional role in regulating the transcription of the HOMER1 gene, which acts a vital role in post-synaptic density and neurotransmission. HOMER1 protein is a key molecule at the post-synaptic membrane and constructs a polymeric network at post-synaptic density with SHANK3 (Hayashi et al. 2009), and this network could let HOMER1 be involved in regulating the function of postsynaptic receptors, such as serotonin receptor, dopamine D1 receptor, $N$-methyl-D-aspartate (NMDA) glutamate receptor and other receptors (Dell'aversano et al. 2009; Iasevoli et al. 2009). Those receptors related to serotonin, dopamine and glutamate were well-known to be associated with psychiatric disorders or suicidal behavior. The other proteins playing important roles in the polymeric network are worthy to be explored for their roles in the etiology of psychiatric disorders and suicidal behavior.

Besides, rs2290639 is located in the promoter region of an uncharacterized gene and might also exert its functional role through affecting the transcription of this gene. However, these hypotheses should be investigated by further experimental approaches. In addition, we did not find any difference in allelic frequencies neither or in any of the models between MDD and HC. It seems that rs2290639 is not associated with MDD in Hong Kong Chinese, although HOMER1 might have a role in animal model under stress condition (Orsetti et al. 2008; Lominac et al. 2005). Furthermore, the negative results with MDD might be owing to the relatively moderate sample size of MDD and HC.

For the psychometric properties of subjects, we found that there was a close correlation between impulsiveness and NEO personality five factors in SA patients and MDD patients, which provides a possible way to assess the impulsiveness of patients through subjects' personality profiles for Hong Kong Chinese as similarly reported in Caucasians (Miller et al. 2012a). Additionally, MDD patients had a significant higher score in HADS suggesting that HADS is also a reliable scale in measuring the depression status for Hong Kong Chinese. Moreover, the lower levels of employment in SA and MDD patients suggested that the worse psychological status may bring a reduced rate of employment for Hong Kong SA and MDD patients, which reconfirmed that these disorders would cause great suffering to their family and bring a heavy burden to the social healthcare system.

One limitation of this study was that lifetime history of suicide attempts relied on self-reports from the subjects, which may likely lead to recall bias. However, we attempted to overcome this limitation by semi-structured clinical interview with experienced clinical psychiatrists. Moreover, the relatively modest sample size might affect the validity of polymorphic association study. Although neither of the power in homozygous model nor in heterozygous model has a power above $80 \%$, the power in recessive model with a stronger effect size could achieve a power of $83.1 \%$. Nonetheless, the negative association of rs2290639 with MDD should be interpreted with caution. Besides, the meta-analysis performed in this study should also be interpreted with caution because in Strauss' sample the values of odds ratio and confidence intervals determined in logistic regression analysis have 
not been adjusted for sex, age and Childhood-onset Mood Disorders.

In conclusion, this study suggested that the HOMER1 rs2290639 was significantly associated with susceptibility to SA in Chinese affected by psychiatric disorders. This polymorphism might influence the transcription of the HOMER1 gene as it changes the sequence of the transcription factor binding site. More related genes in post-synaptic density should be investigated to further understanding the etiology of psychiatric disorders and suicidal behavior.

\section{Additional file}

Additional file 1: Table S1. Demographics and psychometric properties of SA, non-SA, MDD and HC. Figure S1. Psychometric properties of SA patients with AA homozygote and SA patients with T-carrier genotypes.

\section{Authors' contributions}

SR: Carry out the DNA extraction and genotyping of samples, statistical analyses of data, preparation of the first draft of the manuscript. MHBL: Recruitment of subjects, diagnosis and assessment of clinical features of subjects, help with drafting and writing of the manuscript. VY: Preparation for genotyping. Handling, processing and storage of DNA samples. YKW: Design of the experiments, help in diagnosis and assessment of subjects, analyses of the data, help with drafting and writing of the manuscript. MMYW: Overall design of the experiments, analyses of the data, help with drafting and writing of the manuscript. All authors read and approved the final manuscript.

\section{Author details}

${ }^{1}$ Croucher Laboratory for Human Genomics, Rm324A, Lo Kwee-Seong Integrated Biomedical Sciences Building, School of Biomedical Sciences, Area 39; The Nethersole School of Nursing, The Chinese University of Hong Kong, Shatin, N.T., Hong Kong. ${ }^{2}$ Department of Psychiatry, Shatin Hospital, The Chinese University of Hong Kong, 33 Ah Kong Kok Street, Shatin, N.T., Hong Kong.

\section{Acknowledgements}

All the authors wish to thank all the participants and their family members, the ward staff and other associated helpers who have been very supportive of this study. Financial support from Health and Medical Research Fund (HMRF, Ref: 12131101) and the funding from Croucher Foundation donated in 2004 are acknowledged.

\section{Competing interests}

The authors declare that they have no competing interests.

\section{Human and animal rights and Informed consent}

All procedures followed were in accordance with the ethical standards of the responsible committee on human experimentation (institutional and national) and with the Helsinki Declaration of 1975, as revised in 2000 (5). Written Informed consent was obtained from all patients for being included in the study.

Received: 15 January 2016 Accepted: 24 May 2016

Published online: 17 June 2016

\section{References}

Altshuler D, Brooks LD, Chakravarti A, Collins FS, Daly MJ, Donnelly P, Gibbs RA, Belmont JW, Boudreau A, Leal SM, Hardenbol P, Pasternak S, Wheeler DA, Willis TD, Yu FL, Yang HM, Zeng CQ, Gao Y, Hu HR, Hu WT, Li CH, Lin W, Liu SQ, Pan H, Tang XL, Wang J, Wang W, Yu J, Zhang B, Zhang QR, Zhao HB, Zhao H, Zhou J, Gabriel SB, Barry R, Blumenstiel B, Camargo A, Defelice
M, Faggart M, Goyette M, Gupta S, Moore J, Nguyen H, Onofrio RC, Parkin M, Roy J, Stahl E, Winchester E, Ziaugra L, Shen Y, Yao ZJ, Huang W, Chu $X$, He YG, Jin L, Liu YF, Shen YY, Sun WW, Wang HF, Wang Y, Wang Y, Wang $Y$, Xiong XY, Xu L, Waye MMY, Tsui SKW, Xue H, Wong JTF, Galver ILM, Fan JB, Murray SS, Oliphant AR, Chee MS, Montpetit A, Chagnon F, Ferretti V, Leboeuf M, Olivier JF, Phillips MS, Roumy S, Sallee C, Verner A, Hudson TJ, Frazer KA, Ballinger DG, Cox DR, Hinds DA, Stuve LL, Kwok PY, Cai DM, Koboldt DC, Miller RD, Pawlikowska L, Taillon-Miller P, Xiao M, Tsui LC, Mak W, Sham PC, Song YQ, Tam PKH, Nakamura Y, Kawaguchi T, Kitamoto T, Morizono T, Nagashima A, Ohnishi Y, Sekine A, Tanaka T, Tsunoda T, Deloukas P, Bird CP, Delgado M, Dermitzakis ET, Gwilliam R, Hunt S, Morrison J, Powell D, Stranger BE, Whittaker P, Bentley DR, Daly MJ, de Bakker PIW, Barrett J, Fry B, Maller J, McCarroll S, Patterson N, Pe'er I, Purcell S, Richter DJ, Sabeti P, Saxena R, Schaffner SF, Varilly P, Stein LD, Krishnan L, Smith AV, Thorisson GA, Chen PE, Cutler DJ, Kashuk CS, Lin S, Abecasis GR, Guan WH, Munro HM, Qin ZHS, Thomas DJ, McVean G, Bottolo L, Eyheramendy S, Freeman C, Marchini J, Myers S, Spencer C, Stephens M, Cardon LR, Clarke G, Evans DM, Morris AP, Weir BS, Tsunoda T, Mullikin JC, Sherry ST, Feolo M, Zhang HC, Zeng CQ, Zhao H, Matsuda I, Fukushima Y, Macer DR, Suda E, Rotimi CN, Adebamowo CA, Ajayi l, Aniagwu T, Marshall PA, Nkwodimmah C, Royal CDM, Leppert MF, Dixon M, Peiffer A, Qiu RZ, Kent A, Kato K, Niikawa N, Adewole IF, Knoppers BM, Foster MW, Clayton EW, Muzny D, Nazareth L, Sodergren E, Weinstock GM, Wheeler DA, Yakub I, Gabriel SB, Richter DJ, Ziaugra L, Birren BW, Wilson RK, Fulton LL, Rogers J, Burton J, Carter NP, Clee CM, Griffiths M, Jones MC, McLay K, Plumb RW, Ross MT, Sims SK, Willey DL, Chen Z, Han H, Kang L, Godbout M, Wallenburg JC, Archeveque PL, Bellemare G, Saeki K, Wang HG, An DC, Fu HB, Li Q, Wang Z, Wang RW, Holden AL, Brooks LD, McEwen JE, Bird CR, Guyer MS, Nailer PJ, Wang VO, Peterson JL, Shi M, Spiegel J, Sung LM, Witonsky J, Zacharia LF, Kennedy K, Jamieson R, Stewart J, Consortium IH (2005) A haplotype map of the human genome. Nature 437(7063):1299-1320. doi:10.1038/Nature04226

Ango F, Robbe D, Tu JC, Xiao B, Worley PF, Pin JP, Bockaert J, Fagni L (2002) Homer-dependent cell surface expression of metabotropic glutamate receptor type 5 in neurons. Mol Cell Neurosci 20(2):323-329

Baum AE, Akula N, Cabanero M, Cardona I, Corona W, Klemens B, Schulze TG, Cichon S, Rietschel M, Nothen MM, Georgi A, Schumacher J, Schwarz M, Abou Jamra R, Hofels S, Propping P, Satagopan J, Detera-Wadleigh SD, Hardy J, McMahon FJ (2008) A genome-wide association study implicates diacylglycerol kinase eta (DGKH) and several other genes in the etiology of bipolar disorder. Mol Psychiatry 13(2):197-207. doi:10.1038/ sj.mp.4002012

Bjelland I, Dahl AA, Haug TT, Neckelmann D (2002) The validity of the Hospital Anxiety and Depression Scale. An updated literature review. J Psychosom Res 52(2):69-77

Boston RC, Sumner AE (2003) STATA: a statistical analysis system for examining biomedical data. Adv Exp Med Biol 537:353-369

Brakeman PR, Lanahan AA, OBrien R, Roche K, Barnes CA, Huganir RL, Worley PF (1997) Homer: a protein that selectively binds metabotropic glutamate receptors. Nature 386(6622):284-288. doi:10.1038/386284a0

Cartharius K, Frech K, Grote K, Klocke B, Haltmeier M, Klingenhoff A, Frisch M, Bayerlein M, Werner T (2005) MatInspector and beyond: promoter analysis based on transcription factor binding sites. Bioinformatics 21(13):2933-2942. doi:10.1093/bioinformatics/bti473

Corruble E, Damy C, Guelfi J (1999) Impulsivity: a relevant dimension in depression regarding suicide attempts? J Affect Disord 53(3):211-215

Dell'aversano C, Tomasetti C, lasevoli F, de Bartolomeis A (2009) Antipsychotic and antidepressant co-treatment: effects on transcripts of inducible postsynaptic density genes possibly implicated in behavioural disorders. Brain Res Bull 79(2):123-129. doi:10.1016/j.brainresbull.2009.01.006

Dong X, Navratilova P, Fredman D, Drivenes O, Becker TS, Lenhard B (2010) Exonic remnants of whole-genome duplication reveal cis-regulatory function of coding exons. Nucleic Acids Res 38(4):1071-1085. doi:10.1093/nar/gkp1124

Duberstein PR (1995) Openness to experience and completed suicide across the second half of life. Int Psychogeriatr 7(02):183-198

Dupont WD, Plummer WD Jr (1990) Power and sample size calculations. A review and computer program. Control Clin Trials 11(2):116-128

Eggert J, Levendosky A, Klump K (2007) Relationships among attachment styles, personality characteristics, and disordered eating. Int J Eat Disorder 40(2):149-155. doi:10.1002/Eat.20351 
Fiskerstrand C, Lovejoy E, Quinn J (1999) An intronic polymorphic domain often associated with susceptibility to affective disorders has allele dependent differential enhancer activity in embryonic stem cells. FEBS Lett 458(2):171-174

Giuffrida R, Musumeci S, D'Antoni S, Bonaccorso CM, Giuffrida-Stella AM, Oostra BA, Catania MV (2005) A reduced number of metabotropic glutamate subtype 5 receptors are associated with constitutive homer proteins in a mouse model of fragile X syndrome. J Neurosci 25(39):89088916. doi:10.1523/Jneurosci.0932-05.2005

Goldney RD, Fisher LJ, Wilson DH, Cheok F (2002) Mental health literacy of those with major depression and suicidal ideation: an impediment to help seeking. Suicide Life Threat Behav 32(4):394-403

Govek EE, Newey SE, Akerman CJ, Cross JR, Van der Veken L, Van Aelst L (2004) The $\mathrm{X}$-linked mental retardation protein oligophrenin-1 is required for dendritic spine morphogenesis. Nat Neurosci 7(4):364-372. doi:10.1038/Nn1210

Gurling HM, Brynjolfsson J (2001) Genomewide genetic linkage analysis confirms the presence of susceptibility loci for schizophrenia, on chromosomes 1q32.2, 5q33.2, and 8p21-22 and provides support for linkage to schizophrenia, on chromosomes 11q23.3-24 and 20q12.1-11.23. Am J Hum Genet 68(4):661-673

Hawton K, van Heeringen K (2009) Suicide. Lancet 373(9672):1372-1381. doi:10.1016/S0140-6736(09)60372-X

Hayashi MK, Tang C, Verpelli C, Narayanan R, Stearns MH, Xu RM, Li H, Sala C, Hayashi Y (2009) The postsynaptic density proteins Homer and Shank form a polymeric network structure. Cell 137(1):159-171. doi:10.1016/j. cell.2009.01.050

Higgins JPT, Thompson SG (2004) Controlling the risk of spurious findings from meta-regression. Stat Med 23:1663-1682

Horesh N, Rolnick T, lancu I, Dannon P, Lepkifker E, Apter A, Kotler M (1997) Anger, impulsivity and suicide risk. Psychother Psychosom 66(2):92-96

lasevoli F, Tomasetti C, Ambesi-Impiombato A, Muscettola G, de Bartolomeis A (2009) Dopamine receptor subtypes contribution to Homer1a induction: insights into antipsychotic molecular action. Prog Neuropsychopharmacol Biol Psychiatry 33(5):813-821. doi:10.1016/j.pnpbp.2009.02.009

Kato A, Ozawa F, Saitoh Y, Fukazawa Y, Sugiyama H, Inokuchi K (1998) Novel members of the Vesl/Homer family of PDZ proteins that bind metabotropic glutamate receptors. J Biol Chem 273(37):23969-23975. doi:10.1074/jbc.273.37.23969

Leung CM, Ho S, Kan CS, Hung CH, Chen CN (1993) Evaluation of the Chinese version of the Hospital Anxiety and Depression Scale. A cross-cultural perspective. Int J Psychosom 40(1-4):29-34

Leung CM, Wing YK, Kwong PK, Lo A, Shum K (1999) Validation of the ChineseCantonese version of the Hospital Anxiety and Depression Scale and comparison with the Hamilton Rating Scale of Depression. Acta Psychiatr Scand 100(6):456-461

Levinson DF, Holmans P, Straub RE, Owen MJ, Wildenauer DB, Gejman PV Pulver AE, Laurent C, Kendler KS, Walsh D, Norton N, Williams NM, Schwab SG, Lerer B, Mowry BJ, Sanders AR, Antonarakis SE, Blouin JL, DeLeuze JF, Mallet J (2000) Multicenter linkage study of schizophrenia candidate regions on chromosomes 5q, 6q, 10p, and 13q: schizophrenia linkage collaborative group III. Am J Hum Genet 67(3):652-663. doi:10.1086/303041

Li SX, Lam SP, Yu MW, Zhang J, Wing YK (2010) Nocturnal sleep disturbances as a predictor of suicide attempts among psychiatric outpatients: a clinical, epidemiologic, prospective study. J Clin Psychiatry 71(11):1440-1446

Lominac KD, Oleson EB, Pava M, Klugmann M, Schwarz MK, Seeburg PH, During MJ, Worley PF, Kalivas PW, Szumlinski KK (2005) Distinct roles for different Homer1 isoforms in behaviors and associated prefrontal cortex function. J Neurosci 25(50):11586-11594. doi:10.1523/Jneurosci.3764-05.2005

Lovejoy EA, Scott AC, Fiskerstrand CE, Bubb VJ, Quinn JP (2003) The serotonin transporter intronic VNTR enhancer correlated with a predisposition to affective disorders has distinct regulatory elements within the domain based on the primary DNA sequence of the repeat unit. Eur J Neurosci 17(2):417-420. doi:10.1046/j.1460-9568.2003.02446.x

Mann JJ (2003) Neurobiology of suicidal behaviour. Nat Rev Neurosci 4(10):819-828. doi:10.1038/nrn1220

Mathelier A, Zhao X, Zhang AW, Parcy F, Worsley-Hunt R, Arenillas DJ, Buchman S, Chen CY, Chou A, lenasescu H, Lim J, Shyr C, Tan G, Zhou M, Lenhard B, Sandelin A, Wasserman WW (2014) JASPAR 2014: an extensively expanded and updated open-access database of transcription factor binding profiles. Nucleic Acids Res 42(Database issue):D142-D147. doi:10.1093/nar/gkt997
Messeguer X, Escudero R, Farre D, Nunez O, Martinez J, Alba M (2002) PROMO: detection of known transcription regulatory elements using speciestailored searches. Bioinformatics 18(2):333-334

Miller M, Shuman JD, Sebastian T, Dauter Z, Johnson PF (2003) Structural basis for DNA recognition by the basic region leucine zipper transcription factor CCAAT/enhancer-binding protein alpha. J Biol Chem 278(17):1517815184. doi:10.1074/jbc.M300417200

Miller JD, Zeichner A, Wilson LF (2012a) Personality correlates of aggression: evidence from measures of the five-factor model, UPPS model of impulsivity, and BIS/BAS. J Interpers Violence 27(14):2903-2919. doi:10.1177/0886260512438279

Miller M, Azrael D, Barber C (2012b) Suicide mortality in the United States: the importance of attending to method in understanding population-level disparities in the burden of suicide. Annu Rev Public Health 33:393-408. doi:10.1146/annurev-publhealth-031811-124636

Naisbitt S, Kim E, Tu JC, Xiao B, Sala C, Valtschanoff J, Weinberg RJ, Worley PF, Sheng M (1999) Shank, a novel family of postsynaptic density proteins that binds to the NMDA receptor/PSD-95/GKAP complex and cortactin. Neuron 23(3):569-582. doi:10.1016/S0896-6273(00)80809-0

Orsetti M, Di Brisco F, Canonico PL, Genazzani AA, Ghi P (2008) Gene regulation in the frontal cortex of rats exposed to the chronic mild stress paradigm, an animal model of human depression. Eur J Neurosci 27(8):2156-2164. doi:10.1111/j.1460-9568.2008.06155.x

Orsetti M, Di Brisco F, Rinaldi M, Dallorto D, Ghi P (2009) Some molecular effectors of antidepressant action of quetiapine revealed by DNA microarray in the frontal cortex of anhedonic rats. Pharmacogenet Genomics 19(8):600-612. doi:10.1097/Fpc.0b013e32832ee573

Patton JH, Stanford MS, Barratt ES (1995) Factor structure of the Barratt impulsiveness scale. J Clin Psychol 51(6):768-774

Pennacchio LA, Bickmore W, Dean A, Nobrega MA, Bejerano G (2013) Enhancers: five essential questions. Nat Rev Genet 14(4):288-295

Pinaud E, Aupetit C, Chauveau C, Cogne M (1997) Identification of a homolog of the $C$ alpha $3^{\prime} /$ hs 3 enhancer and of an allelic variant of the $3^{\prime} \operatorname{lgH} / \mathrm{hs} 1,2$ enhancer downstream of the human immunoglobulin alpha 1 gene. Eur J Immunol 27(11):2981-2985. doi:10.1002/eji.1830271134

Rao ST, Lam MHB, Wing YK, Yim LCL, Chu WCW, Yeung VSY, Waye MMY (2015) Beneficial effect of phosphatidylcholine supplementation in alleviation of hypomania and insomnia in a Chinese bipolar hypomanic boy and a possible explanation to the effect at the genetic level. SpringerPlus 4:235. doi:10.1186/s40064-015-1002-y

Rietschel M, Mattheisen M, Frank J, Treutlein J, Degenhardt F, Breuer R, Steffens M, Mier D, Esslinger C, Walter H, Kirsch P, Erk S, Schnell K, Herms S, Wichmann HE, Schreiber S, Jockel KH, Strohmaier J, Roeske D, Haenisch B, Gross M, Hoefels S, Lucae S, Binder EB, Wienker TF, Schulze TG, Schmal C, Zimmer A, Juraeva D, Brors B, Bettecken T, Meyer-Lindenberg A, MullerMyhsok B, Maier W, Nothen MM, Cichon S (2010) Genome-wide association-, replication-, and neuroimaging study implicates HOMER1 in the etiology of major depression. Biol Psychiatry 68(6):578-585. doi:10.1016/j. biopsych.2010.05.038

Roche KW, Tu JC, Petralia RS, Xiao B, Wenthold RJ, Worley PF (1999) Homer 1b regulates the trafficking of group I metabotropic glutamate receptors. J Biol Chem 274(36):25953-25957

Rosenthal N, Berglund EB, Wentworth BM, Donoghue M, Winter B, Bober E, Braun T, Arnold HH (1990) A highly conserved enhancer downstream of the human MLC1/3 locus is a target for multiple myogenic determination factors. Nucleic Acids Res 18(21):6239-6246

Roy A (2001) Characteristics of cocaine-dependent patients who attempt suicide. Am J Psychiatry 158(8):1215-1219. doi:10.1176/appi. ajp.158.8.1215

Roy A, Rylander G, Sarchiapone M (1997) Genetics of suicides. Family studies and molecular genetics. Ann NY Acad Sci 836:135-157

Schmidt HD, Duman RS (2007) The role of neurotrophic factors in adult hippocampal neurogenesis, antidepressant treatments and animal models of depressive-like behavior. Behav Pharmacol 18(5-6):391-418. doi:10.1097/Fbp.0b013e3282ee2aa8

Schork NJ, Fallin D, Thiel B, Xu XP, Broeckel U, Jacob HJ, Cohen D (2001) The future of genetic case-control studies. Adv Genet 42:191-212. doi:10.1016/S0065-2660(01)42023-2

Segal DL, Hersen M, Van Hasselt VB (1994) Reliability of the Structured Clinical Interview for DSM-III-R: an evaluative review. Compr Psychiatry 35(4):316-327 
Serge A, Fourgeaud L, Hemar A, Choquet D (2002) Receptor activation and homer differentially control the lateral mobility of metabotropic glutamate receptor 5 in the neuronal membrane. J Neurosci 22(10):3910-3920

Sher $L$ (2011) Brain-derived neurotrophic factor and suicidal behavior. QJM 104(5):455-458. doi:10.1093/qjmed/hcq207

Shiraishi-Yamaguchi Y, Furuichi T (2007) The Homer family proteins. Genome Biol 8(2):206. doi:10.1186/gb-2007-8-2-206

Spellmann I, Rujescu D, Musil R, Mayr A, Giegling I, Genius J, Zill P, Dehning S, Opgen-Rhein M, Cerovecki A, Hartmann AM, Schafer M, Bondy B, Muller N, Moller HJ, Riedel M (2011) Homer-1 polymorphisms are associated with psychopathology and response to treatment in schizophrenic patients. J Psychiatr Res 45(2):234-241. doi:10.1016/j. jpsychires.2010.06.004

Strauss J, McGregor S, Freeman N, Tiwari A, George CJ, Kovacs M, Kennedy JL (2012) Association study of early-immediate genes in childhood-onset mood disorders and suicide attempt. Psychiatry Res 197(1-2):49-54. doi:10.1016/j.psychres.2011.11.022

Su Al, Wiltshire T, Batalov S, Lapp H, Ching KA, Block D, Zhang J, Soden R, Hayakawa M, Kreiman G, Cooke MP, Walker JR, Hogenesch JB (2004) A gene atlas of the mouse and human protein-encoding transcriptomes. Proc Natl Acad Sci USA 101(16):6062-6067. doi:10.1073/pnas.0400782101

Szumlinksi KK, Lominac KD, Kleschen MJ, Oleson EB, Dehoff MH, Schwarz MK, Seeburg PH, Worley PF, Kalivas PW (2005) Behavioral and neurochemical phenotyping of Homer1 mutant mice: possible relevance to schizophrenia. Genes Brain Behav 4(8):273-288. doi:10.1111/j.1601-183X.2005.00180.X

Thean LF, Li HH, Teo YY, Koh WP, Yuan JM, Teoh ML, Koh PK, Tang CL, Cheah PY (2012) Association of Caucasian-identified variants with colorectal cancer risk in Singapore Chinese. PLoS ONE 7(8):e42407. doi:10.1371/journal. pone.0042407

Trikalinos TA, Salanti G, Zintzaras E, loannidis JPA (2008) Meta-analysis methods. Adv Genet 60:311-334. doi:10.1016/S0065-2660(07)00413-0

Tu JC, Xiao B, Yuan JP, Lanahan AA, Leoffert K, Li M, Linden DJ, Worley PF (1998) Homer binds a novel proline-rich motif and links group 1 metabotropic glutamate receptors with IP3 receptors. Neuron 21(4):717-726. doi:10.1016/S0896-6273(00)80589-9
Varnik P (2012) Suicide in the world. Int J Environ Res Public Health 9(3):760771. doi:10.3390/ijerph9030760

Wang J, Yi L, Guo X, He D, Li H, Guo G, Wang Y, Zou H, Gu Y, Tu W (2014) Lack of association of the CD247 SNP rs2056626 with systemic sclerosis in Han Chinese. Open Rheumatol J 8:43-45

Wender PH, Kety SS, Rosenthal D, Schulsinger F, Ortmann J, Lunde I (1986) Psychiatric disorders in the biological and adoptive families of adopted individuals with affective disorders. Arch Gen Psychiatry 43(10):923-929

Winokur G, Tsuang M (1975) The lowa 500: suicide in mania, depression, and schizophrenia. Am J Psychiatry 132(6):650-651

Yang J, McCrae RR, Costa PT, Dai XY, Yao SQ, Cai TS, Gao BL (1999) Crosscultural personality assessment in psychiatric populations: the NEOPI-R in the People's Republic of China. Psychol Assess 11(3):359-368. doi:10.1037/1040-3590.11.3.359

Yao S, Yang H, Zhu X, Auerbach RP, Abela JR, Pulleyblank RW, Tong X (2007) An examination of the psychometric properties of the Chinese version of the Barratt Impulsiveness Scale, 11 th version in a sample of Chinese adolescents. Percept Mot Skills 104(3 Pt 2):1169-1182

Yin X, Low HQ, Wang L, Li Y, Ellinghaus E, Han J, Estivill X, Sun L, Zuo X, Shen C, Zhu C, Zhang A, Sanchez F, Padyukov L, Catanese JJ, Krueger GG, Duffin KC, Mucha S, Weichenthal M, Weidinger S, Lieb W, Foo JN, Li Y, Sim K, Liany H, Irwan I, Teo Y, Theng CT, Gupta R, Bowcock A, De Jager PL, Qureshi AA, de Bakker PI, Seielstad M, Liao W, Stahle M, Franke A, Zhang X, Liu J (2015) Genome-wide meta-analysis identifies multiple novel associations and ethnic heterogeneity of psoriasis susceptibility. Nat Commun 6:6916. doi:10.1038/ncomms7916

Zeng Z, Wang T, Li T, Li Y, Chen P, Zhao Q, Liu J, Li J, Feng G, He L, Shi Y (2011) Common SNPs and haplotypes in DGKH are associated with bipolar disorder and schizophrenia in the Chinese Han population. Mol Psychiatry 16(5):473-475. doi:10.1038/mp.2010.86

\section{Submit your manuscript to a SpringerOpen ${ }^{\odot}$ journal and benefit from:}

- Convenient online submission

- Rigorous peer review

- Immediate publication on acceptance

- Open access: articles freely available online

- High visibility within the field

- Retaining the copyright to your article

Submit your next manuscript at springeropen.com 